\title{
CRITIQUES AND APPRECIATION ON ORIENTALISM IN THE STUDY OF ISLAM
}

\author{
Abdul Fattah \\ State Islamic University (UIN) Mataram \\ Jl. Pendidikan No.35, Dasan Agung Baru, Selaparang, Kota Mataram, Nusa Tenggara Barat \\ E-mail: fath_smart@yahoo.com
}

\begin{abstract}
Critiques and Appreciation on Orientalism in the Study of Islam. This article describes critiques on orientalism as well as appreciates orientalist works which have positive values in Islamic studies that requires "reassessment". This is because orientalism is a distinctive discipline that has a strong historical value between the West and the East (read: Islam) after the medieval European renaissance. This discipline was initially used as a Western political tool to exploit the East—both aggression and imperialism. However this discipline deserves careful attention by removing prejudices-geopolitical and historical revenge in the orientalists' objective judgments. The work produced by such orientalists cannot be solely underestimated. Some orientalists merely using a scientific or semi-scientific approach have continuously produced "magnum opus" and contributed to the development of Islamic studies such as Hadith index, Quranic dictionary, and Encyclopedia of Islam.
\end{abstract}

Keywords: orientalism; hadith index; Quranic dictionary; encyclopedia of Islam.

\begin{abstract}
Abstrak: Kritik dan Apresiasi terhadap Orientalisme dalam Kajian Keislaman. Artikel ini memaparkan kritik terhadap orientalisme dan mengapresiasi karya-karya orientalis yang memiliki nilai positif dalam lingkup studi keislaman yang memang memerlukan "penilaian kembali”. Hal ini dipicu oleh adanya kesadaran historis bahwa orientalisme merupakan sebuah disiplin khusus yang memiliki nilai kesejarahan panjang antara dunia Barat dan Timur (baca: Islam), terutama pasca-era Renaissans Eropa pada Abad Pertengahan. Tampaknya sedari awal disiplin ini dijadikan sebagai instrumen politik Barat untuk mengeksploitasi Timur, bahkan untuk melancarkan kepentingan agresi dan imperialisme. Namun diakui pula bahwa di tangan Orientalis yang menjunjung tinggi nilai-nilai obyektifitas, disiplin ini memiliki atensi maksimal penuh kehati-hatian, dengan menyampingkan dimensi prejudis geo-politis dan historis. Dikarenakan menjunjung tinggi objektifitas, karya-karya yang ditorehkan oleh orientalis dalam haluan ini tidak perlu diremehkan atau dipandang sebelah mata. Sejarah panjang menunjukkan bahwa orientalis yang menggunakan pendekatan objektif atau semi-objektif, terus berkarya dan menghasilkan “magnum opus" yang patut diapresiasi seperti indeks hadis, kamus Alquran, dan ensiklopedi Islam.
\end{abstract}

Kata kunci: orientalisme; indeks hadis; kamus Alquran; ensiklopedi Islam.

\section{Introduction}

The study of orientalism has had a long tradition in the Western academic world (read: Europe). But the orientalism that has developed for a long time was considered likely to be used as an ideological tool by the West to carry out new hegemony and imperialism towards the East, especially the Islamic world. This fact, in the view of Komaruddin Hidayat, has caused stigma in the Muslim world that whatever Western scholars said about Islam was then suspected.' Bachelor

Komarudin Hidayat, "Oksidentalisme: Dekonstruksi of Islamic Higher Education (PTKI) alumnus who takes the Islamic studies program at the Western College, cannot be separated from this reality. After returning, they were "suspected" of being contaminated by orientalist thoughts.

To date, the researchers differed in determining the beginning of orientalism. ${ }^{2}$ Some

terhadap Barat" in Hassan Hanafi, Oksidentalisme: Sikap Kita Terhadap Tradisi Barat translated by M. Nadjib Buchori (Jakarta: Paramadina, 2000), p. xv.

2 According to Mahmud Hamdi Zaqzuq, orientalism is studies conducted by Westerners on East-Islam relating to language, literature, history, beliefs, legislation, and civilization are in a very common scope. Meanwhile Edward 
of them said that orientalism began to exist since the $10^{\text {th }}$ century, while some others argued, orientalism emerged after the Crusades took place around 1097-1292 AC. There are also those who said that orientalism has begun their activities in the 13th century in Andalusia (Spain), when the attacked of the Spanish Crusaders against Muslim reached the climax. At that time King Qastalah, Alfonso, told Michel Scoot to conduct research on science and civilization that had been achieved by Muslim. Scoot gathered pastors in a church to compile a translation program for Arabic books into European language. ${ }^{3}$

The study of orientalism developed so rapidly in the nineteenth century. When dozens of French scholars brought by Napoleon entered Egypt in 1789 , they produced about 23 large volumes of knowledge or deep understanding related to Egyptology. The strengthening of orientalism in the nineteenth century had speed the way for the expansion of imperialism which had forced their will on to their colonized people. Orientalism is used for Western political tactical interests over the East-Islamic world. In the Indonesian context, orientalism had used as a tool of Dutch colonization through the hands of $C$. Snouck Hurgronje (1857-1936 AC) who had investigated Aceh for 5 years (1898-1903) to tact Aceh and Indonesian Muslim as a whole. ${ }^{4}$

W. Said underlined that orientalism is fundamentally a political doctrine willed over the Orient because the Orient was weaker than the West, which elided the Orient's difference with its weakness. See al-Istisrâqwa al-Khalfiyyah al-Fikriyyah li al-Sirâ alHadāri (Kairo: Dar: al-Manar, 1989), p. 18; and Edward W. Said, Orientalism, (London: Penguin, 1991), p. 204.

3 See also Achmad Satori Ismail, Orientalisme dalam Pandangan Orang Timur, (Jakarta: Jurnal Ma'rifah, 1994), p. 4.

4 C. SnouckHugronje (1857-1936) was seen as an "architect" who was most instrumental in designing Islamic policy in Indonesia when the Dutch colonized Indonesia before the arrival of Japan. In this context, he was seen as having great service in establishing the KantoorVoorInlandscheZaken (Office of Indigenous Affairs) in 1899 which incidentally this office was established to coincide with the launching of the Ethical Politiek (Ethical Politics) of the natives, especially after the Dutch Queen's speech in 1901. This indigenous affair is an independent institution authorized to give advice to colonial governments concerning religion other than Christianity. In carrying out its duties this office, is directly responsible to the Governor General. The advisors of this office, must have studied eastern issues at Leiden University, in addition to understanding Indonesian and Arabic. The task of this office, in addition to conducting research in the fields of language, customs, anthropology, religious, political and cultural tendencies of the natives and Arab groups,
As a scientific discipline, orientalism actually does not need to be suspected. It must be known in depth by prioritizing scientific objectivity, scientific ethics, and eliminating ideological, cultural, and geo-political prejudice. In this case, as Islamic scholar or researcher, many of us should study orientalism as well as reassess it wisely in a wider perspective.

\section{Said's Reinterpretation of Orientalism}

Etymologically, orientalism is derived from the words "orient" and "ism". The term "orient" means "East" and meanwhile "ism" means "understanding". ${ }^{5}$ The ultimate opponent of this term is occidentalism, which consists of the word "occident" which means "West" and "ism" means "understanding". According to Webster's dictionary, orientalism is a "study of Eastern culture". The main character of this study is called "orientalist" which means "a student of Eastern culture". ${ }^{6}$

Orientalism in Arabic is called "الإِستِتُشَرَاقُ It is a part of verb (f'il) “㳊” which means

is also tasked with giving advice to the Governor-General in these matters. See AkibSuminto, The Political Islam of the Dutch East Indies (Jakarta: LP3ES, 1985), 99, 106 and 111.

5 In recent years, the term occidentalism has been conceived to be a science which at the same time has become a strong obsession of an Egyptian Muslim scholar; DR. Hassan Hanafi. For Hanafi, if orientalism is the study of Islamic civilization by researchers from other civilizations that have an emotional structure that is different from the structure of the civilization it teaches, then occidentalism is the science that is opposite or even opposite to it. If Orientalism deliberately takes the position of partiality until the level of pent-up ill will, then Occidentalism expresses the ability of "ego" as a neutral emotion in looking at "the other", studying it, and turning it into an object, after so long "the other" become subjects make other parties as objects. It's just that, Occidentalism is built on a neutral "ego" and is not ambitious to seize power, and only wants liberation. He did not want to discredit other cultures, and only knew their formations and structures. "Ego" Occidentalism is cleaner, objective and neutral compared to "ego" Orientalism. The task of this new science according to Hassan Hanafi is to return the Non-European emotions to their place of origin, eliminate their alienation, reconnect with their old roots, put them into a realistic position to then analyze them directly and take an attitude towards European civilization that is considered by everyone as a source of knowledge. Whereas in fact it is a civilization aggressor for other civilizations that experienced reincarnation in the era of revitalization and its revival. See Hassan Hanafi, Muqaddimah f'llm al-Istigrâb (Beirut: al-Hamra ', 1992), p. 25-26.

6 Noah Webster, "Webster's New Twentieth Century Dictionary of the English Language" (New York: Simon dan Schuster, 1979), p. 1261. 
"heading east and wearing people's clothing". While the term "orientalist" contained in al-

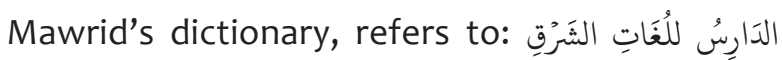
وَفْنُُْْنِهِ وَحَضَارَتِهِ Eastern languages, their arts and culture."” From this root word, it can be generally concluded that

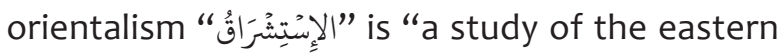
works performed by non-Eastern people." ${ }^{8}$

In terms of terminology, Orientalism is:

$$
\begin{aligned}
& \text { الإِستِتِشَراقُ: الدراسات الغربية المتعلقة بالشرق } \\
& \text { الاسلامى فى لغته وادبه وتاريخه وعقائدته وتشريعاته }
\end{aligned}
$$

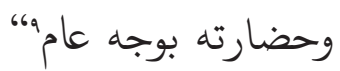

"Studies conducted by Westerners on the East and Islam in terms of language and literature, history, beliefs, legislation, and civilization are in a very common scope." There are also those who see orientalism as no more than just a "movement" which concerns on research in science, tradition, civilization, and Islamic cultures with the aim of exploring the secrets, nature, character, and thoughts, because of the progress and strength of the Islamic community. ${ }^{10}$ Abidin Ja'far defines orientalism as "a teaching or understanding that learns and collects all knowledge relating to language, religion, culture, history, earth science, ethnography, ethnology, literature, art originating from the Eastern world" which includes North Africa (Near East, Middle East and Far East)".12

7 Munir al-Ba'labaqi, al-Mawrid: A Modern Arabic English Diictionary, (Beirut: Dar al-'اlm li al-Malâyin, 1974), p. 638.

${ }^{8}$ Sa'ad al-Marsafi, al-Mustashriqūnwa al-Sunnah (Kuwait: Maktabah al-Manâr al-Islāmiyyah, 1994), p. 9.

${ }_{9}^{9}$ Mahmud Hamdi Zaqzuq, al-Istisrâq wa al-Khalfiyyah alFikriyyah li al-Sirâ al-Hadâri (Kairo: Dar: al-Manar, 1989), p. 18.

10 Sa'id al-Dīn al-Sayyid Salih, Jaringan Konspirasi Menentang Islam translated by Muhammad Thalib (Yogyakarta: Wihdah Press, 1999), p. 117.

"To establish definitively about Eastern understanding is rather difficult. Because the East understanding is certainly different for the Japanese, Indians, or Arabs, also for the Germans, British, and Americans. Likewise, there are different views for people in the early and middle centuries and in the modern century, especially after the American continent was put forward. Rudi Paret (an orientalist) acknowledges that there was no strict limit to the notion of the word "East". The most important thing for him is the problem of material about Orientalism itself. Conclusion This paragraph was quoted by Abidin Ja'far in Orientalism and the Study of Arabic, (Yogyakarta: CV Bina Usaha, 1987), p.7.

${ }^{12}$ Further, according to Bernard Lewis, the term "Middle East" was discovered in 1902 by an American water historian
Whereas Edward W. Said views orientalism as a "library" or "information archive" that is held together, where the archives are a group of ideas and a set of unifying values that in various ways prove effective in explaining the behavior of Eastern people, supplying the East with a certain mentality, genealogy, and specific climate. And the most importantly, these ideas allow Europeans to deal with and see Eastern people as a phenomenon that has regular characteristic. ${ }^{13}$ Furthermore, Said stated that orientalism can be considered as a way of writing, insight, and studies that are made regular (or oriented) dominated by imperatives, perspectives, and ideological biases, which are considered suitable for the East. In this context, the East is taught, researched, regulated, and assessed in certain typical ways. ${ }^{14}$ But Said saw that knowledge about the East, Islam and the Islamic community, in general, was produced not only from domination and confrontation, but also from the antipathy of culture. Thus,

named Alfred Thayer Mahan, to refer to the zone / area located between Arabia and India, with its center - according to the point of view of water experts - is the Persian Gulf. This relatively recent "geographical expression" was reported by The Times and later by the British Government. And along with the newer term, "Near East", is including a new name even though it is not categorized in modern terms. The two terms also include historical relics with the West-Europe as the central parameter, which then the surrounding areas are grouped by departing from this Western-European region. In the historical "optics" of Peter Mansfield, before World War I, it was common to distinguish between the Near East which included Greece, Bulgaria, Turkey, the Mediterranean and Egypt; and the Middle East which includes Arabia, Mesopotamia, the Persian Gulf, Iran and Afghanistan. Then gradually, the term "Middle East" is used to refer to the two, except regions which are not included in this term, namely Greece and Bulgaria in the West, and Afghanistan in the East. But the term Middle East includes Sudan and sometimes Libya and even other North African countries. According to the most recent survey, the countries and territories including the Middle East are: the Arabian Peninsula region (including Saudi Arabia, the Republic of Yemen, the Democratic Republic of South Yemen, Kuwait, Bahrain, Qatar, the ceasefire region and Oman), Egypt, Iraq, Israel, Jordan, Lebanon, Iran, Sudan, Syria and Turkey, the Hashimiyya kingdom. If this zone is combined, the area is around 3,726,000 square miles. See Bernard Lewis, The Middle East and The West (London: Lowe \&Brydone (Printers), 1968), p. 9; and Peter Mansfield, "Introduction: the Region Define," in The Middle East: A Political and Economic Survey, ed. Peter Mansfield (London: Oxford University Press, 1973), p.1.

${ }^{13}$ Edward W. Said, al-Istishrāq; al-Ma'rifah, al-Sultlah, al-Inshä', translated into Arabic by Kamal Abu Dib (Beirut: Muassasah alAbhath al-'Arabiyyah, 1981), p.72.

${ }^{14}$ Edward W. Said, al-Istishrâq..., p.214. 
what is quoted about East and Islam does not represent the real situation. ${ }^{15}$ Said's theory in any cases, underlines this affirmation.

\section{The Birth of Orientalism: Historical Glance Perspective}

When Andalusia reached their heyday, the Western clergies came to Andalusia to "learn" to Islamic scholars. The knowledge they studied was philosophy, medicine, exact sciences and social studies. They were also spirit to intensively translate the Quran and Arabic language knowledge into their language. Among them (the clergyman), was St. Gerbert from France. In 999 AD, he succeeded in occupying the highest position in the Roman church. He was also ordained as a Pope after completing studies at the Andalusian College. Also Piere Ainere (1092-1156 AD) and Gerard de Ceremona (1114-1187 AD), who belonged to the first batch of pastors who had received education and lessons at the College. ${ }^{16}$

Since then, many Western scholars have been interested in studying Islam and Arabic. Arabic science and literature were continuously copied into their language, until the 18 th century, many of them built colleges which they specialized in teaching Islamology, such as Badawy College. ${ }^{17}$

The situation started to turn around. Since the $15^{\text {th }}$ century $A D$, the relationship between the Islamic world and Europe was the relationship between "al-Maghlūb" and "Ghālib", where since that century, Islamic countries began to be colonized by European countries. Together with the invaders, the missionaries also shared the news throughout the colonies. Both missionaries and invaders both have interests in the Islamic world. To carry out colonial politics, colonizers needed adequate knowledge of the customs, religion and culture of the country's children in general. The same knowledge is also needed by missionaries to spread Christianity among natives. On the basis of this collaboration, the

${ }^{15}$ Edward W. Said, Covering Islam (New York: Pantheon Books, 1981), p.155.

16 Muhammad Baharun, Isu Zionisme Internasional (Yogyakarta: Pustaka Pelajar, 1997), p. 49-50.

${ }^{17}$ Muhammad Baharun, Isu Zionisme Internasional..., p.50
Gospel of the Jesuits entered to the French colonies, Anglicanism into the British colony, Protestantism into the Dutch colony. Both parties collect information from the colony, processed it, conduct further research and conclude, then offer it as recommendations to their respective officials. ${ }^{18}$

In the view of Mahmud Hamdi Zaqzuq, the $19^{\text {th }}$ century $A D$ and the $20^{\text {th }}$ century were the actual emergence of the Orientalism movement. At the end of the $18^{\text {th }}$ century, exactly March 1795 $A D$, the French Government launched a revolution by intensifying the development of schools that studied Eastern languages. At this time, Eastern studies were specifically focused on practical considerations, especially when considering the accessibility of Eastern languages in contributing to advancing literature and other knowledge. Furthermore, the movement of orientalism in France began to take the form of its scientific characteristics in the hands of Silvestre de Sacy (died 1838 AD) who became the "priest" of the orientalists of his time. He was very instrumental in making Paris as the center for studying Arabic language and culture aimed at students and scholars from various parts of Europe to study. On this basis, Paret said that orientalism had formed independent disciplines / patent in the $19^{\text {th }}$ century AD. 19

In the first half of the $19^{\text {th }}$ century, orientalist began to establish scientific study institutions to study all aspects of Easternism in several European and American countries. The institute was first established in Paris in 1822 AD then similar institutions were also established in Great Britain and Ireland in 1823 AD after that, also established East-American scientific study institute in $1824 \mathrm{AD}$ finally stood also East scientific research institutions East-German in Germany on 1845 AD. ${ }^{20}$

Orientalists have held an International Conference for the first time massively in Paris in

\footnotetext{
${ }^{18}$ Rifyal Ka'bah, Islam dan Serangan Pemikiran (Jakarta: Granada Nadia, 1994), p.30-31.

${ }^{19}$ Mahmud Hamdi Zaqzuq, al-Istisrāqwa al-Khalfiyyah ..., p. $47-48$.

${ }^{20}$ Mahmud Hamdi Zaqzuq, al-Istisrāqwa al-Khalfiyyah ..., p.50-51.
} 
1873 AD to coordinate their Orientalism activities. After that, followed by similar conferences more than 30 times. $^{21}$

In the next development, after the colonization left and imposed restrictions on the movement of missionaries in several independent Islamic countries, Orientalism and the Center of Islamic studies in the West did not lose the market or it still survived. Even it developed to serve new needs in the name of dialogue and so forth. However, orientalism is actually used for regional studies that develop in several Western countries, especially the United States and the Third World. It is not only a tool for Western countries, but also for industrial countries such as Japan and Korea that have interests in the Islamic world. ${ }^{22}$ Thus, orientalism tends to advantage the Western countries and industrial ones, especially from political, colonial, and economical sides.

\section{Orientalism Targets: From Within Critiques}

The study of orientalism implied many critiques. In fact, orientalists are not in one line; some are objective, some are not objective, and the rest are full of prejudice because of the "shallowness" of their studies. On the other hand, the orientalists who study orientalism are inseparable from the following targets:

\section{1) Religious Targets}

This religious target according to Mahmud Hamdi Zaqzuq has existed since the existence of orientalism. In this framework they did: first, weakens the element of Islamic power which became the source of superiority of Islamic thought by spreading doubts and anxiety about the truth of Islamic thought. At the same time, instilling ideological assumptions, Islam was a derivation of Judaism and Christianity. Second, protecting the Christian group from their bad plans launched and hid the nature of their existence, and warned them of the dangers of Islamization for their religion. Third, bring "good news" as well as want to Christianize Muslims. ${ }^{23}$

\footnotetext{
${ }^{21}$ Mahmud Hamdi Zaqzuq, al-Istisräqwa al-Khalfiyyah ..., p.52.

${ }^{22}$ Rifyal Ka'bah, Islam dan Serangan ..., p.31.

23 Mahmud Hamdi Zaqzuq, al-Istisrāqwa al-Khalfiyyah ..., p.86.
}

\section{2) Colonial Targets}

The crusade was over. The war was actually a religious war. The war that had been waged by Western imperialism had essentially made Muslims fall bowed under the grip of colonialism. Under the pretext of being kind, the imperialist view was directed at the relationship of culture and science. In fact, the study mostly benefited invaders, because they could recognized more in aspects of their weakness and the potential they had. With this weakness they can exploit the Islamic world. A simple example is what was done by C. Snouck Hurgronje, especially Aceh (between 1898-1903) with a study of Islam and it was civilizations in Saudi Arabia and Egypt. ${ }^{24}$

By this target, it seems that Albert Hourani didn't deny it, especially if it was associated with a certain period. But according to Hourani, there were also some of the Orientalists who strongly opposed the imperial wisdom of their country. Among them is E.G. Browne in the United Kingdom who supported the constitutional revolution in Iran, Louis Massignon was a supporter of the Algerian independence movement and C. Snouk Hurgronje had used the influence he had with the intention of forming a more wise and open attitude towards colonized nations. In addition, what became the central tradition of the $19^{\text {th }}$ century Islamic studies stated in Germany was not marked by the above position. Because, both Germany and Austria, do not have direct power over Muslim countries in Asia and Africa. ${ }^{25}$

\section{3) Political Targets}

This target tends to be the case in later of Arab countries. After these countries became independent, the Western countries formed Embassies in these countries. Deliberately in these countries other local attaches were placed. With that skill, the attaché was expected to be able to hold "familiar" communication with political figures and the press, so that they can detected and recognize the political direction outlined by

\footnotetext{
${ }^{24}$ Muhammad Baharun, Isu Zionisme Internasional...., p.56.

25 Albert Haourani, Islam dalam Pandangan Eropa translated by Imam Baihaqi and Ahmad Baidlowi (Yogyakarta: PustakaPelajar, 1998), p.67.
} 
the countries concerned. ${ }^{26}$

Orientalists also carry out intelligence activities in Islamic countries and send their results to colonial countries. These orientalists in general were not from intellectuals, but from politicians who served the interests of Western colonizers. An example is Hanotoux, Duke Drouco, St. Hiller and others who are members of parliament in their respective countries, in addition to being advisors to the country's foreign ministry. ${ }^{27}$

\section{4) Science Targets}

According to Muhsin Mahdi, (Iran philosopher), the last phenomenon (especially from 18th century) suggested Germany scientists to realize that Western should study from the East. Mahdi wrote;

"There was something fundamentally wrong with the excesses of scientism or rationalism or philosophy in the modern West and that it was necessary to supplement it with the poetic, religious, and spiritual dimension of human life, which can be found in the East. The West was incomplete and needed to complete itself with what it had somehow lost during its recent development. It needed to unify the shattered pieces of human experience; and the way to achieve this unity was to learn about it from the East where it continued to exist and where the missing part—the poetic—had survived." ${ }^{28}$

In the age of enlightenment in Europe, there were a small number of orientalists who carried out the study of orientalism after reading religious manuscripts and their depth, so that they realized that the Islamic tract was very close to other heavenly tracts. Islamic tract also reinforce what was contained in their books such as the problem of faith in God, ethical issues and call upon goodness. This group usually makes the slightest mistake in assessing Islam. If there were mistakes made, it was solely because of differences in vision and interpretation. Therefore, the results of their studies are closer to the truth

\footnotetext{
${ }^{26}$ Muhammad Baharun, Isu Zionisme Internasional...., p.58.

27 Sa'id al-Dīn al-Sayyid Salih, Jaringan Konspirasi Menentang..., p.120.

${ }^{28}$ See Muhsin Mahdi, 'Orientalism and the Study of Islam Philosophy',Journal of Islam Studies 1(1990), p. 73-98.
}

than their counterparts who have motivated political interests in their Eastern research. ${ }^{29}$

\section{5) Economical Targets}

This target was seen in the period before the colonialization of Islamic countries occurred in two centuries; $19^{\text {th }}$ and $20^{\text {th }}$ centuries Westerners exactly put the great attention to expanding their trading area in the East to get raw materials and other raw materials at much cheaper prices, which would encourage the development of their industry. On this basis, they are very urged to travel to Islamic countries, to know them more, to study the geographical dimensions of nature and their agricultural areas. Not infrequently they interact well with local residents. However, behind that, Westerners want to make Eastern countries the market for their products. ${ }^{30}$

It's clear all the targets gave us wider perspective that orientalism was studied and done due to vested interest (belongs specially to the West). For instance, religious target at spatial weakens the element of Islamic power which became the source of superiority of Islamic thought by spreading doubts and anxiety about the truth of Islamic thought. Besides, in term of colonial targets, the study mostly benefited invaders, because they could recognized more in aspects of their weakness and the potential they had. With this weakness they can exploit the Islamic world. By political targets, orientalists also carry out intelligence activities in Islamic countries and send their results to colonial countries. These orientalists in general were not from intellectuals, but from politicians who served the interests of Western colonizers.

By science targets, it's understood that orientalists who carried out the study of orientalism after reading religious manuscripts and their depth, so that they realized that the Islamic tract was very close to other heavenly tracts. Islamic tract also reinforce what was contained in their books such as the problem

${ }^{29}$ Mahmud Hamdi Zaqzuq, al-Istisrâqwa al-Khalfiyyah ..., p.88-89.

3o Mahmud Hamdi Zaqzuq, al-Istisrâqwa al-Khalfiyyah ..., p.89 and Muhammad Baharun, Isu Zionisme Internasional...., p. $57-58$. 
of faith in God, ethical issues and call upon goodness. And the last, economic targets express that Westerners exactly put the great attention to expanding their trading area in the East to get raw materials and other raw materials at much cheaper prices, which would encourage the development of their industry. On this basis, they are very urged to travel to Islamic countries, to know them more, to study the geographical dimensions of nature and their agricultural areas.

\section{Orientalists Positive Works}

To be honest, the first and main contribution orientalism to Islamic world is text production of Islamic studies in big scale that enrich Islamic literatures which benefits afterwards. Orientalists works didn't only contribute from quantity aspect, but also the most important is from quality and methodology side.

Many Muslim scholar take advantage out from orientalists works in big scale. Orientalism provided advantageous Islamic literatures in bounty, various, as well as complete format. Thus, many Muslim scholars prefer to read the orientalists works as references rather than Muslim works that help them in conducting research today. Due to the fact that they found Islamic world and literatures were analyzed more rationally and even liberally. Afterwards, the orientalist works are perceived more interesting than traditional Muslim scholar works in rigid dan dogmatic style. So forth, the Western works on Islamic studies are studied and cited more as alternative literatures.

The work of Western orientalists in the sector of Islamic studies based on Western traditions that were only about two hundred years old, was indeed impossible to compare with the work of Muslim scientists for more than a thousand years. But objectively, we cannot underestimate the work produced by orientalists. If they conduct an objective study, they will arrive at the truth. In its long history, there are still orientalists who only use a scientific or semi-scientific approach, especially when Islamic studies in various institutions in the West are no longer fully under religious organizations and / or theology faculties, and after they are no longer from religious figures alone.

It is from this circle which the results of work had contributed greatly to the development of Islamic studies among Muslim and non-Muslim. Even most of their works, cannot be rivaled by Muslim scientific works in the same field. We can take a sample of some of the works:

\section{1) Hadith Index}

The greatest orientalist work that was widely used by Islamic scholars was the Hadith Concordance et Indices de la Tradition Musulmane, under the care of the Dutch Orientalist named A.J. Wensick; and Index of Qur'ân, Lee Koran Analisee, by French Orientalists named Jules la Beaume and Edward Montet. The first consists of 7 volumes with thousands of pages, and the second was only 1 volume. Both of these books, can be used by Muslims with a calm heart, because all of them are compiled based on books from the hadith books and the Mushaf of Quran. ${ }^{31}$

Especially regarding the hadith index above, until now there is no better and more systematic index than that. This book is compiled based on the hadith books used in Islamic circles, especially Kutub al-Sittah. By using this index, we can look for narrators of the hadith, the main quotation of matan (text) hadith, and in the book where we can find it. ${ }^{32}$

The difficulty found was that this index was compiled based on the hadith books published during the period of its preparation (before 1939). Meanwhile, the hadith books have been published again by various publishers and in various editions, so sometimes the pages and volumes of hadith books designated by this index are no longer exact. Therefore, this index requires repairs and adjustments to the new edition of the hadith books.

This problem, has received attention from the Encyclopaedia Hadith Committee at Al-Azhar University (Egypt), which has for more than a decade made efforts to compile the hadith as a whole based on the theme and the sahîh and

\footnotetext{
${ }^{31}$ Rifyal Ka'bah, Islam dan Serangan ..., , p.67.

${ }^{32}$ Rifyal Ka'bah, Islam dan Serangan ..., , p.67.
} 
not sahîh order so that it is easy to become a reference. ${ }^{33}$

While the works of Jules le Beaume and Montet has been translated into Arabic by Muhammad Fu'ad 'Abd al-Baqi entitled Tafsil verse the Quran al-Hakim (the details of the verses of the Quran). As the name implies, this book is a dictionary that classifies Quran verses according to themes. This effort is similar to the arrangement of the Shorter Oxford Bible reconfiguring Christian Scriptures such as the composition of a modern book, so that its content becomes clearer by looking at the contents. ${ }^{34}$

The Le Beaume and Montet systems received an attention from the Arabic Language Institute (Majma 'al-Lughah al-Arabiyyah) in Cairo, Egypt. This institution has formed an index writing team and at the same time the Quran dictionary was more detailed than previously published, but easy to use. The team, which was formed for the first time in 1941, included members of a famous orientalist, namely Sir H.A.R. Gibb. Even though Gibb only contributed to determining the systematics, this reality actually showed the recognition from the Islamic community about orientalist scholarship in the field of Arabs and Islam. After several times experiencing repairs and replacements, as well as improvements to team members, this index can only be published in 1970.35

\section{2) Quranic Dictionary}

In the sector of the dictionary Quran, so A Dictionary and Glossary of the Quran by British Orientalists, Jhon Penrice, includes those widely used among Muslim, especially those who use English. This dictionary was published the first time in London on $1873 \mathrm{AD}$ and has been reprinted several times. A. Yusuf Ali, who translated Quran into English with the title The Holy Quran: Text, Translation and Commentary which was first published in Lahore, in 1934, refers to this dictionary. Then this dictionary was also used by Mohammad Marmaduke Pickthall in

33 Rifyal Ka'bah, et.al. Pendidikan Islam di Indonesia danMesir (Buku I) (Kairo: KBRI, 1983), p.113.

${ }^{34}$ Rifyal Ka'bah, Islam dan Serangan ..., p.69.

35 Rifyal Ka'bah, Islam dan Serangan ..., p.69.
The Meaning of the Glorius Koran (1952). He was also used by Muhammad Asad in The Massage of the Quran (1980), and by T.B. Irving in The Quran: The First American Version (1985), even though these translators or commentators did not mention it directly. ${ }^{36}$

In lexicography, it cannot be forgotten is also the work of the famed Edward William Lane, an Arabic-English Lexicon, which is the work of drafting the summit. The preparation of this lexicon Lane started the second visit to Egypt in 1842 AD Lane had left Egypt and returned to England seven years later after feeling the preparation of mature for his dictionary. He died 4 days after finishing perfecting the lexicon blueprint, so he never saw the lexicon circulating. ${ }^{37}$

Lane is the most comprehensive works in the field of modern Arabic lexicography. This lexicon not only explains the meaning of words and sentences, but also provides many examples of poetry and prose, mathematical information, critical comments, and so on. In this case, Lane has combined three major Arabiclanguage works that are the source in a set of books. The three works are al-Qâmus al-Muhît by Najm al-Din al-Fayruzzabadi, Tāju 'al-'Arūs by al-Murtada al-Zubaydi and al-Sihhah by Jawhari. Lane's dictionary was widely used by Muslims and non-Muslims. ${ }^{38}$

\section{3) Encyclopedia of Islam}

In encyclopedias, the biggest contribution of the orientalists was the Encyclopedia of Islam which in English and French editions, was published by the Brill publisher in Leiden, the Netherlands. The encyclopedia, which has undergone these improvements, is the work of a number of the leading orientalists in the world, for many years, where the first half $(A-L)$ was completed in 1979.39 Especially for the improved edition, the edited edition of a number of famous Muslim writers has been included can be in line

\footnotetext{
${ }^{36}$ Rifyal Ka'bah, Islam dan Serangan ..., p.70.

${ }^{37}$ Rifyal Ka'bah, Islam dan Serangan ..., p.70.

${ }^{38}$ Rifyal Ka'bah, Islam dan Serangan ... , p.71.

39 Reynold A. Nicholson, A Literary History of the Arabs, (Cambridge: Cambridge University Press, 1979), p.479.
} 
with the systematics set by the editor. Until now, 5 volumes have been published (about a thousand pages each, folio size paper, with a smaller letter setting)..$^{40}$

Remember that the decades of time required for the completion of all of this encyclopedia set, then the publisher Brill saw the need to issue a miniature entitled The Shorter Encyclopedi of Islam, edited by Sir H.A.R. Gibb and Kramers. As the name implies, it only describes the problem in a concise manner, but it cannot be separated from its general nature and was easy to carry because it was only one volume. Therefore, this encyclopedia was very useful for beginners and students who master English. ${ }^{41}$

If we uncover the weaknesses of orientalist studies on Islam, that does not mean we deny their contribution in the development of Islamic studies. However, in certain aspects, they have helped our understanding of the phenomenon, expression, and translation of Islam. Apart from the weaknesses of their studies, quite a lot of things can be learned from orientalists. This of course still maintains a critical and objective attitude. Therefore, we must remain objective and acknowledge that orientalism has not a small contribution to the studies of eastern, especially Islam such as Reynold Nicholson and Arthur J. Arberry. This group prefers to be called "Islamisis" rather than Orientalist. Among them were John L. Esposito, Karen Armstrong, Martin Lings, Annemarie Schimmel, John O. Voll, Ira M. Lapidus, Marshal GS Hodgson, Leonard Binder, and Charles Kurtzman.

Karel Steenbrink revealed two main reasons why Muslim scholars need and must read Orientalist writings: first, handbooks in all sector of science, such as economics, sociology, psychology, engineering, medicine, etc., now comes from the Western world. If the knowledge of Islam does not want to be left behind from these sciences, then he is obliged to seek relations or dialogue with the science of religion among Western scholars and scholars, especially in relation to the results they have achieved in the field of

\footnotetext{
${ }^{40}$ Reynold A. Nicholson, A Literary History... , p.73.

${ }^{41}$ Reynold A. Nicholson, A Literary History..., p.74.
}

Islamic religion. Second, in collecting materials, storing and publishing old texts, orientalism has a rich and old tradition. Often sources of Islamic treasures can be extracted more easily in libraries and manuscript collections in the West than in ancient mosques in the Islamic world.

If Islamic scholars closes themselves from the development of studies on the same subject in the West, it basically closes themselves from the possibility of new developments. In the scientific tradition, conducting research on a problem, the first step must be a review of the results of research of people who have discussed the problem before. Covering the results of Western research from this discussion, it would certainly be detrimental to the research of Muslim scholars themselves. ${ }^{42}$

In line with Karel Steenbrink's thoughts, Muslim intellectual Ahmad Syafi'i Maarif also had a "good impression" on orientalism. According to him, the best way to deal with orientalist works were not only to imitate their sincerity in producing creative works, but also to develop an extra-critical attitude towards their interpretation of Islamic doctrine. The attitude that only suspects is another form of intellectual powerlessness..$^{43}$

An important note for reviewers of Islamic civilization must decide on a clear, objective, and consistent attitude towards orientalism. First of all, at the present time many Islamic scholars from Muslim develop their academic authority based on their academic experience with the orientalists.

\section{Conclusion}

Orientalism actually concerns on the relationship between the West and the East for a long time. This relationship is still a problem until now. The term of West was created by Europeans during the colonial period. They see themselves as the West and see the people of Asia and Africa as the East who can be exploited and manipulated for their interests.

${ }^{42}$ Karel Steenbrink, "Berdialog dengan Karya-karya Kaum Orientalis”, Jurnal Ulumul Quran, No. 2, 1992, p.25.

${ }^{43}$ Ahmad Syafi'i Maarif, "Orientalisme Mengapa Dicurigai”, Jurnal Ulumul Quran, No. 2, 1992, p.3. 
From the beginning, we can see the form of partiality in orientalism, namely 'East' which is seen from outside of the East itself. This alignment became clearer when we saw that the development of orientalism was far more advanced than the development of occidentalism. For example, Westerners who study all aspects concerning on the East and its culture. But at the same time, it can be said that there is no meaningful assessment of the East towards Western nations and their culture - except for Hassan Hanafi's obsession with his mega-projects. In addition to the wide acceptance of Western science and technology and the Western culture by the East, again at the same time, there has not been a systematic study of the West from an Eastern perspective.

To be noted, orientalists are not in one line; some are objective, some are not objective, and the rest are full of prejudice because of the "shallowness" of their studies. Thus, Islamic studies and the Islamic world are still fortunate in the presence of objective orientalist studies of Islam.

\section{References}

Ba'labaqi, al-, Munir, al-Mawrid: A Modern Arabic English Diictionary, Beirut: Dar al-'Ilm li alMalāyin, 1974.

Baharun, Muhammad, Isu Zionisme Internasinal. Yogyakarta: Pustaka Pelajar, 1997.

Hanafi, Hassan, Muqaddimahfi'llm al-Istigrāb, Beirut: al-Hamra', 1992.

Haourani, Albert, Islam dalam Pandangan Eropa translated by Imam Baihaqiand Ahmad Baidlowi, Yogyakarta: Pustaka Pelajar, 1998.

Hidayat, Komarudin. "Oksidentalisme: Dekonstruksi terhadap Barat" in Hassan Hanafi, Oksidentalisme: Sikap Kita Terhadap Tradisi Barat translated by. M. Nadjib Buchori. Jakarta: Paramadina, 2000.

Ismail, Achmad Satori, Orientalisme dalam Pandangan Orang Timur, Jakarta: Jurnal Ma'rifah, 1994.
Ja'far, Abidin, Orientalisme dan Studi Tentang Bahasa Arab. Yogyakarta: CV Bina Usaha, 1987.

Ka'bah, Rifyal, Islam dan Serangan Pemikiran. Jakarta: Granada Nadia, 1994. , Pendidikan Islam di Indonesia dan Mesir, Kairo: KBRI, 1983

Lewis, Bernard, The Middle East and The West. London: Lowe \& Brydone (Printers), 1968.

Maarif, Ahmad Syafii, "Orientalisme Mengapa Dicurigai", in Jurnal Ulumul Quran, No. 2, 1992.

Mahdi, Muhsin. 'Orientalism and the Study of Islam Philosophy', Journal of Islam Studies, 1990.

Mansfield, Peter. "Introduction: the Region Define," The Middle East: A Political and Economic Survey, ed. Peter Mansfield. London: Oxford University Press, 1973.

Marsafi, Sa'ad, al-, al-Mustashriqūnwa al-Sunnah, Kuwait: Maktabah al-Manār al-Islāmiyyah, 1994.

Nicholson, Reynold A, A Literary History of the Arabs. Cambridge: Cambridge University Press, 1979.

Said, Edward W, Covering Islam. New York: Pantheon Books, 1981. , al-Istishrāq; al-Ma'rifah, al-Sultlah, alInshâ translated by. Kamal Abu Dib. Beirut: Muassasah al-Abhath al-'Arabiyyah, 1981. , Orientalism.London: Penguin, 1991.

Salih, Sa'id al-Din al-Sayyid, Jaringan Konspirasi Menentang Islam translated by. Muhammad Thalib. Yogyakarta: Wihdah Press, 1999.

Steenbrink, Karel, "Berdialog dengan Karyakarya Kaum Orientalis”, JurnalUlumul Quran, No. 2, 1992.

Suminto, Akib. Politik Islam Hindia Belanda. Jakarta: LP3ES, 1985.

Webster, Noah. "Webster's New Twentieth Century Dictionary of the English Language". New York: Simon dan Schuster, 1979.

Zaqzuq, Mahmud Hamdi, al-Istisrāqwa al-Khalfiyyah al-Fikriyyah li al-Sirâ al-Hadâri. Kairo: Dar: alManar, 1989. 